\title{
PENGARUH PELAYANAN KESEHATAN DAN \\ PENYELENGGARAAN MAKANAN TERHADAP TINGKAT \\ KESADARAN HIDUP SEHAT BAGI NARAPIDANA \\ DI LEMBAGA PEMASYARAKATAN KELAS IIB SLAWI
}

\author{
Andi Rahmanto dan Maufur \\ Lapas Slawi dan Universitas Pancasakti Tegal \\ Rahmanto.andi39@gmail.com
}

\begin{abstract}
The study is done to analyze influence in partial and simultaneous between variables health services and penyenggaraan food to the level of consciousness healthy life residents under the jurisdiction of corrective services in a correctional institution class IIB slawi. Methods used is the method quantitative descriptive, by using 162 respondents. An instrument used is the questionnaire covered with a scale likert that has been tested validity and reliability, test results show the questionnaire valid and reliable/reliabel. The testing of hypotheses carried out using of linear equations multiple. The research results show that: and in partial: (1) health services berperngaruh positive on awareness healthy life; (2) the convention food have had a positive impact on awareness healthy life, (3) simultaneously shows that health services and the implementation of food have had a positive impact on awareness healthy life for prisoners in lapas class IIB slawi
\end{abstract}

Password: health services, the food, awareness healthy life.

\section{PENDAHULUAN}

Lembaga Pemasyarakatan (Lapas) Kelas IIB Slawi merupakan instansi publik yang berorientasi pada pelayanan kehidupan narapidana. Pengertian Narapidana, menurut Pasal 1 angka 7 Undang-Undang No. 12 Tahun 1995 tentang Pemasyarakatan (UU 12/1995), adalah terpidana yang menjalani pidana hilang kemerdekaan di Lapas. Sedangkan pengertian terpidana adalah seseorang yang dipidana berdasarkan putusan pengadilan yang telah memperoleh kekuatan hukum tetap (Pasal 1 angka 6 UU 12/1995). Oleh karena itu, selama perkara tersebut masih menempuh proses peradilan dan berbagai upaya hukum selanjutnya, orang tersebut belum dikatakan sebagai narapidana.

Negara Republik Indonesia mengakui dan menjunjung tinggi hak asasi manusia dan kebebasan dasar manusia sebagai hak yang secara kodrati melekat dan tidak terpisah dari manusia yang harus dilindungi, dihormati, dan ditegakkan demi peningkatan martabat kemanusisan, kesejahteraan, kebahagiaan, dan kecerdasan serta keadilan.

Hak Asasi Manusia (HAM) adalah hak dasar yang dimiliki manusia sejak manusia itu dilahirkan. Hak asasi dapat dirumuskan sebagai hak yang melekat dengan kodrat sebagai manusia yang bila tidak ada hak tersebut, mustahil dapat hidup sebagai manusia. Hak ini dimiliki oleh manusia semata- 
mata karena ia manusia, bukan karena pemberian masyarakat atau pemberian negara, maka hak asasi manusia itu tidak tergantung dari pengakuan manusia lain, masyarakat lain, atau negara lain.

Sebagai negara hukum hak-hak narapidana harus dilindungi oleh hukum dan penegak hukum khususnya para petugas di Lapas, sehingga merupakan sesuatu yang perlu bagi negara hukum untuk menghargai hak-hak asasi narapidana sebagai warga masyarakat yang harus diayomi walaupun telah melanggar hukum. Disamping itu narapidana perlu diayomi dari perlakuan tidak adil, misalnya penyiksaan, tidak mendapatkan fasilitas yang wajar dan tidak adanya kesempatan untuk mendapatkan remisi. Yang paling penting adalah tercapainya tujuan pemasyarakatan itu sendiri yaitu mengembalikan warga binaan menjadi warga yang baik dan mencegah agar tidak mengulangi perbuatan (Nugroho, Suara Merdeka, 24 Oktober 2016)

Dalam Undang-undang Republik Indonesia Nomor 12 Tahun 1995 tentang Permasyarakatan menyebutkan bahwa salah satu hak dari narapidana adalah mendapatkan pelayanan kesehatan dan penyelenggaraan makanan yang layak. Pelayanan kesehatan dan penyelenggaraan makanan yang memenuhi syarat kesehatan atau makanan sehat adalah makanan higienis, bergizi, dan berkecukupan. Makanan yang higienis adalah yang tidak mengandung kuman penyakit atau zat yang dapat membahayakan kesehatan. Makanan yang bergizi adalah yang cukup mengandung karbohidrat, lemak, protein, mineral, vitamin, dalam jumlah yang seimbang sesuai dengan kebutuhan. Makanan yang berkecukupan adalah yang dapat memenuhi kebutuhan tubuh pada usia dan kondisi tertentu. Selain memenuhi persyaratan pokok tersebut, perlu diperhatikan juga cara memasak makanan, suhu makanan pada saat disajikan, dan bahan.

Pemenuhan pelayanan kesehatan ini tidak hanya menyangkut penciptaan lingkungan yang baik, perlakukan yang sama, tapi termasuk pula pembenahan pelayanan kesehatan secara manusiawi yang diarahkan pada tingkatan harkat dan martabat, sehingga diharapkan dapat mengembangkan suatu masyarakat yang berkepribadian, yang saling menghormati dan menjunjung tinggi hak asasi manusia.

Salah satu konsep dalam sistem pemasyarakatan adalah memperlakukan orang lebih manusiawi dari pada sistem kepenjaraan (Warga Binaan Pemasyarakatan) WPB dalam melaksanakan program pembinaan harus dalam kondisi sehat. Namun permasalahan yang terjadi di dalam Lapas Kelas IIB Slawi fasilitas kesehatan yang ada kurang memadai (mobil ambulan dan obat-obatan), kurangnya tenaga paramedis yang melakukan pemeriksaan kesehatan.

Selain permasalahan di atas, tidak semuanya narapidana dalam kondisi sehat, bagi narapidana yang sakit harus mendapatkan pelayanaan kesehatan yang optimal maka dari itu menurut UndangUndang No.23 Tahun 1992 Tentang Kesehatan, kesehatan dan pemenuhan makanan sehat adalah tercapainya kesadaran akan pola hidup sehat, kemampuan dan kemauan hidup sehat setiap penduduk agar dapat mewujudkan hidup sehat yang optimal, berarti setiap orang tanpa memandang ras, agama, politik yang dianut, dan ekonomi, diberikan hak pelayanaan kesehatan dan makanan. Demikian pula bagi narapidana yang sedang menjalani masa pidananya di Lapas harus mempunyai kesadaran akan pola hidup sehat, kemampuan dan kemauan hidup sehat selama menjalani masa hukuman dan selama proses pembinaan kepribadian maupun kemandirian. 
Berdasarkan uraian latar belakang tersebut, penulis tertarik mengkaji tentang pengaruh pelayanan kesehatan dan penyelenggaraan makanan terhadap tingkat kesadaran hidup sehat para warga binaan pemasyarakatan di Lembaga Pemasyarakatan Kelas IIB Slawi .

\section{METODE PENELITIAN}

Penelitian ini dirancang dengan tujuan untuk menganalisis hubungan antar variabel. Rancangan penelitian ini termasuk penelitian korelasinal, yaitu penelitian yang dilakukan dengan maksud menganalisis hubungan antar variabel. Variabel-variabel yang digunakan adalah pelayanan kesehatan, makanan dan tingkat kesadaran hidup sehat sebagaimana diungkapkan dalam hipotesis, masing-masing akan diuraikan dalam indikator yang sesuai dan selanjutnya diturunkan menjadi item pertanyaan dalam instrumen penelitian.

Sampel adalah sebagian dari jumlah dan karakteristik yan dimilki oleh populasi tersebut. Dalam menentukan jumlah sampel dalam penelitian ini menggunakan rumus Slovin. Rumus tersebut dituliskan sebagai berikut (Umar, 2001:47)

$n=\frac{N}{1+N(e)^{2}}$

keterangan:

$\mathrm{n}=$ Jumlah sampel

$\mathrm{N}=$ Jumlah populasi

$\mathrm{e}=$ Tingkat kesalahan

Populasi (N) sebanyak 271orang narapidana Lapas Klas IIB Slawi dengan asumsi taraf kesalahan (e) sebesar 5\%, maka jumlah sampel (n) adalah:

$n=\frac{271}{1+271(0,05)^{2}}=161,54 \approx 162$ narapidana
Maka jumlah sampel dalam penelitian ini adalah sebanyak 162 orang narapidana Lapas Klas IIB Slawi, yang akan dijadikan sampel dalam menjawab pertanyaan kuesioner penelitian ini.

Analisis yang digunakan dalam penelitian ini adalah menggunakan persamaan regresi berganda dengan 3 uji yaitu (1) uji prasyarat meliputi uji validitas dan uji reliabilitas, (2) uji hipotesis meliputi uji Fsimultan dan uji $\mathrm{t}$ parsial serta (3) uji sampel yang terdiri dari uji heteroskedastisitas, uji normalitas, dan uji multikolinearitas.

Dalam menganalisis permasalahan yang dikemukakan dalam penelitian ini, digunakan persamaan regresi berganda, dengan menggunakan Statistical Package for Social Science (SPSS) 20.0.

Secara garis besar, kerangka pikir pengaruh pelayanan kesehatan dan penyelenggaraan makanan terhadap tingkat kesadaran hidup sehat pada naparidana di Lapas Kelas IIB Slawi adalah sebagai berikut :

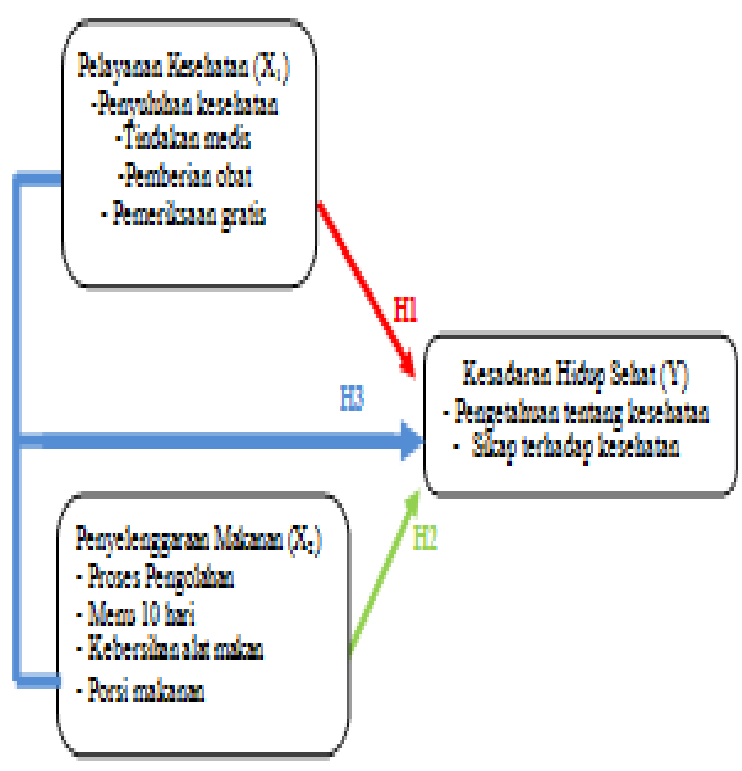

Gambar 1. Kerangka pemikiran 
HASIL PENELITIAN DAN

\section{PEMBAHASAN}

\section{Persamaan Regresi Linear Ber- ganda}

Berdasarkan hasil pengolahan data dengan menggunakan software SPSS 20.0, maka persamaan regresi linear berganda dari data penelitian diperoleh persamaan sebagai berikut:

$Y=14,554+0,105 \times 1+0,678 \times 2$

Tabel 1. Data hasil persamaan regresi linear

\begin{tabular}{|c|c|c|c|}
\hline \multirow{2}{*}{\multicolumn{2}{|c|}{ Model }} & \multicolumn{2}{|c|}{ Unstandardized Coefficients } \\
\hline & & $B$ & Std. Error \\
\hline \multirow{3}{*}{1} & (Constant) & 14,554 & 2,926 \\
\hline & Pelayanan Kesehatan & 0,105 & 0,049 \\
\hline & $\begin{array}{l}\text { Penyelenggaraan } \\
\text { Nakanan }\end{array}$ & 0,678 & 0,080 \\
\hline
\end{tabular}

a. Dependent Variable: Kesadaran Hidup Sehat

Dari Persamaan tersebut dapat diinterpretasikan sebagai berikut:

a) Kontanta $\mathrm{a}=14,554$ menyatakan bahwa jika pelayanan kesehatan dan penyelenggaraan makanan sama dengan nol dan tidak ada perubahan, maka kesadaran hidup sehat narapidana sebesar 14,554.

b) Koefisien regresi b1 $=0,105$ menyatakan bahwa koefisien regresi dari pelayanan kesehatan sebesar 0,105 yang artinya bahwa setiap kenaikan satu satuan, maka pelayanan kesehatan akan menaikkan kesadaran hidup sehat sebesar 0,105.

c) Koefisien regresi b2 $=0,678$ menyatakan bahwa koefisien regresi dari penyelenggaraan makanan sebesar 0,678 yang artinya bahwa setiap kenaikan satu satuan, maka penyelenggaraan kesehatan akan menaikkan kesadaran hidup sehat sebesar 0,678 .

\section{Analisis Koefisien Determinasi $\left(\mathbf{R}^{2}\right)$}

Besarnya kontribusi variabel pelayanan kesehatan (X1) dan penyelenggaraan makanan (X2) terhadap kesadaran hidup sehat (Y) ditunjukkan dengan besarnya koefisien determinasi atau $\mathrm{R}$ square. Hal ini dapat dilihat pada tabel berikut ini:

Tabel 2. Koefisien korelasi dan determinasi pelayanan kesehatan dan penyelenggaraan makanan terhadap kesadaran hidup sehat bagi para narapidana di Lapas Kelas IIB Slawi.

\begin{tabular}{|l|c|r|r|r|}
\hline Model & R & RSquas & Adiusta R Squas & Std Eroo of the Estimat: \\
\hline 1 & 0,628 & 0,395 & 0,387 & 3,084 \\
\hline
\end{tabular}

Besarnya kontribusi variabel pelayanan kesehatan (X1) dan penyelenggaraan makanan (X2) secara bersama-sama terhadap kesadaran hidup sehat $(\mathrm{Y})$ ditunjukkan dengan besarnya koefisien determinasi. Dari tabel di atas diketahui bahwa koefisien determinasinya adalah 0,395 atau $39,5 \%$, artinya pelayanan kesehatan (X1) dan penyelenggaraan makanan (X2) secara bersama-sama mempunyai pengaruh terhadap kesadaran hidup sehat (Y) sebesar $39,5 \%$ dan sisanya sebesar $60,5 \%$ dipengaruhi oleh faktor lain

\section{Uji Prasyarat (Instrumen)}

\section{a. Uji Validitas instrumen}

Uji validitas dilakukan dengan mengkorelasikan masing-masing pertanyaan dengan jumlah skor masingmasing variabel.Hasil keputusan dalam uji ini adalah pertanyaan tersebut dianggap Valid jika rhitung $>$ rtabel, dan dapat digunakan untuk analisis data selanjutnya. Dalam penelitian ini pembacaan menggunakan rtabel sebagai berikut:

a. Nilai df/ degree of freedom sebesar $=$ $\mathrm{n}-2=162-2=160$ 
b. Nilai signifikasi penelitian dalam penelitian ini ditentukan sebesar 0,05

c. Sehingga $r$ tabel $=\operatorname{rtabel}(160 ; 0,05)=$ 0,154

Berikut ini hasil uji validitas pada masing-masing variabel pelayanan kesehatan (X1), penyelenggaraan makanan (X2), dan kesadaran hidup sehat (Y)

Tabel 3 Rekapitulasi hasil uji validitas variabel pelayanan kesehatan.

\begin{tabular}{|c|c|c|c|c|}
\hline No & Pertanyaan & rhitung & rtabel & Keterangan \\
\hline 1 & X1.1 & 0,447 & 0,154 & Valid \\
\hline 2 & X1.2 & 0,458 & 0,154 & Valid \\
\hline 3 & X1.3 & 0,58 & 0,154 & Valid \\
\hline 4 & X1.4 & 0,412 & 0,154 & Valid \\
\hline 5 & $\mathrm{X} 1.5$ & 0,463 & 0,154 & Valid \\
\hline 6 & $\mathrm{X} 1.6$ & 0,365 & 0,154 & Valid \\
\hline 7 & $\mathrm{X} 1.7$ & 0,483 & 0,154 & Valid \\
\hline 8 & $\mathrm{X} 1.8$ & 0,389 & 0,154 & Valid \\
\hline 9 & $\mathrm{X} 1.9$ & 0,518 & 0,154 & Valid \\
\hline 10 & $\mathrm{X} 1.10$ & 0,353 & 0,154 & Valid \\
\hline 11 & $\mathrm{X} 1.11$ & 0,425 & 0,154 & Valid \\
\hline
\end{tabular}

Tabel 4. Rekapitulasi hasil uji validitas variabel penyelenggaraan makanan

\begin{tabular}{|c|c|c|c|c|}
\hline No & Pertanyaan & rhitung & rtabel & Keterangan \\
\hline 1 & $\mathrm{X} 2.1$ & 0,675 & 0,154 & Valid \\
\hline 2 & $\mathrm{X} 2.2$ & 0,683 & 0,154 & Valid \\
\hline 3 & $\mathrm{X} 2.3$ & 0,742 & 0,154 & Valid \\
\hline 4 & $\mathrm{X} 2.4$ & 0,653 & 0,154 & Valid \\
\hline 5 & $\mathrm{X} 2.5$ & 0,710 & 0,154 & Valid \\
\hline 6 & $\mathrm{X} 2.6$ & 0,642 & 0,154 & Valid \\
\hline 7 & $\mathrm{X} 2.7$ & 0,650 & 0,154 & Valid \\
\hline 8 & $\mathrm{X} 2.8$ & 0,535 & 0,154 & Valid \\
\hline
\end{tabular}

Tabel 5. Rekapitulasi hasil uji validitas variabel kesadaran hidup sehat

\begin{tabular}{|c|c|c|c|c|}
\hline No & Pertanyaan & rhitung & rtabel & Keterangan \\
\hline 1 & Y1 & 0,576 & 0,154 & Valid \\
\hline 2 & Y2 & 0,552 & 0,154 & Valid \\
\hline 3 & Y3 & 0,57 & 0,154 & Valid \\
\hline 4 & Y4 & 0,478 & 0,154 & Valid \\
\hline 5 & Y5 & 0,636 & 0,154 & Valid \\
\hline 6 & Y6 & 0,46 & 0,154 & Valid \\
\hline 7 & Y7 & 0,517 & 0,154 & Valid \\
\hline 8 & Y8 & 0,603 & 0,154 & Valid \\
\hline 9 & Y9 & 0,664 & 0,154 & Valid \\
\hline 10 & Y10 & 0,622 & 0,154 & Valid \\
\hline
\end{tabular}

menunjukkan bahwa nilai korelasi (rhitung) tiap item pertanyaan dengan skor nilai yang diperoleh lebih besar dari 0,154, sehingga dapat disimpulkan bahwa item pertanyaan yang digunakan adalah valid dan dapat digunakan dalam analisis data selanjutnya.

\section{b. Uji Reliabilitas instrumen}

Uji reliabilitas dilakukan untuk mengetahui tingkat kekonsistenan item pertnyaan tersebut digunakan dalam penelitian.Hasil keputusan dalam uji ini adalah pertanyaan tersebut dianggap reliabel/terpercaya, jika nilai Cronbach's Alpha $>$ rtabel dan dapat dikatakan item pertanyaan tersebut benar-benar dapat dipercaya sebagai alat pengumpul data. Dalam penelitian ini pembacaan menggunakan rtabel sebagai berikut:

a. Nilai df/ degree of freedom sebesar $=$ $\mathrm{n}-2=162-2=160$

b. Nilai signifikasi penelitian dalam penelitian ini ditentukan sebesar 0,05

c. Sehingga $\mathrm{rtabel}=\operatorname{rtabel}(160 ; 0,05)=$ 0,154

Berikut ini hasil uji reliabilitas pada masing-masing variabel pelayanan kesehatan (X1), penyelenggaraan makanan (X2), dan kesadaran hidup sehat $(\mathrm{Y})$ 
Tabel 6. Hasil uji reliabilitas variabel layanan kesehatan

\begin{tabular}{|c|c|}
\hline Cronbach's Alpha & Noflten: \\
\hline 0,621 & 12 \\
\hline
\end{tabular}

Tabel 7. Hasil uji reliabilitas variabel penyelenggaraan makanan

\begin{tabular}{|c|c|}
\hline Cronbach's Alpha & N ofItems \\
\hline 0,763 & 9 \\
\hline
\end{tabular}

Tabel 8. Hasil uji reliabilitas variabel kesadaran hidup sehat

\begin{tabular}{|c|c|}
\hline Cronbach's Alpha & N of Items \\
\hline 0,732 & 11 \\
\hline
\end{tabular}

Berdasarkan hasil uji reliabilitas yang dilakukan terhadap semua item pertanyaan dalam penelitian ini menunjukkan bahwa semua item pertanyaan dapat dikatakan reliabel/ terpercaya, dengan nilai Cronbach's Alpha sebesar 0,$621 ; 0,763$; dan 0,732 lebih besar dibanding dengan rtabel sebesar 0,154 , dengan demikian semua item pertanyaan dalam setiap variabel dapat dipercaya sebagai alat pengumpul data.

\section{Uji Sampel}

\section{a. Uji Normalitas}

Uji normalitas bertujuan untuk menguji apakah dalam model regresi variabel pengganggu atau residual memiliki distribusi normal. Uji statistik yang digunakan dalam penelitian ini adalah uji statistik non parametrik Kolmogorov-Smirnov (K-S). Hasil output dari pengujian normalitas dengan Kolmogorov-Smirnov adalah sebagai berikut ini.
Tabel 9. Hasil uji normalitas

\begin{tabular}{|c|c|c|}
\hline & & Unataodardized Resitsal \\
\hline $\mathrm{N}$ & & 162 \\
\hline \multirow{3}{*}{ Normal Parameners" } & Mase & OE-? \\
\hline & Std. Deviasion & 3,05452656 \\
\hline & Abrobsese & 0,070 \\
\hline Most Extreme Differexe & Positive & 0,054 \\
\hline & Negative & $-0,070$ \\
\hline Kolmogorov-Smirnov $Z$ & & 0,896 \\
\hline Arrma Siz (2-aided) & & 0.413 \\
\hline
\end{tabular}

Berdasarkan tabel hasil uji normalitas di atas diketahui nilai signifikasi dari Kolmogorov-Smirnov adalah 0,413 lebih besar dari 0,05 , hal ini berarti menunjukkan bahwa data residual berdistribusi normal.

\section{b. Uji heterokedastisitas}

Heterekedastisitas merupakan suatu asumsi kritis dari model linier klasik. Jika asumsi ini tidak dipenuhi dalam suatu model linier maka model dalam penelitian tersebut kurang valid. Berikut ini adalah hasil uji heterokedastisitas.

Tabel 10. Hasil uji heterokedastisitas

\begin{tabular}{|c|c|c|c|c|c|c|}
\hline \multirow{2}{*}{\multicolumn{2}{|c|}{ Model }} & \multicolumn{2}{|c|}{$\begin{array}{c}\text { Unstandardizsd } \\
\text { Coefficients }\end{array}$} & \multirow{2}{*}{\begin{tabular}{|c|}
$\begin{array}{c}\text { Standardizad } \\
\text { Coefficients }\end{array}$ \\
Beta \\
\end{tabular}} & \multirow[t]{2}{*}{$\mathrm{t}$} & \multirow[t]{2}{*}{$\mathrm{Sig}$} \\
\hline & & $\mathrm{B}$ & Std. Error & & & \\
\hline \multirow{3}{*}{1} & (Constant) & 4,011 & 1,818 & & 2,207 &, 029 \\
\hline & Pelayanan Kesehatan & $-0,010$ & 0,031 & $-0,027$ & $-0,313$ & 0,755 \\
\hline & $\begin{array}{l}\text { Penyelenggaraan } \\
\text { Nakanan }\end{array}$ & $-0,034$ & 0,049 & $-0,057$ & $-0,678$ & 0,499 \\
\hline
\end{tabular}

Dari tabel di atas diketahui nilai signifikansi lebih besar dari $0,05 \%$, sehingga nilai $P$. Value dari variabel kualitas pelayanan ternyata tidak ada yang signifikan, hal ini berarti tidak terjadi hiterokedastisitas atau dapat dikatakan model regresi telah lolos uji heterokedastisitas.

\section{c. Uji multikolinearitas}

Salah satu cara untuk melihat ada tidaknya multikolinieritas, dapat dilihat dari nilai tolerance dan nilai variance 
inflation factor (VIF). Ketentuannya adalah apabila nilai tolerance lebih kecil dari 0,10 dan nilai VIF lebih besar dari 10, dapat dikatakan terjadi multikolinieritas. Sebaliknya apabila nilai kualitas pelayanan lebih besar dari 0,10 dan nilai VIF lebih kecil dari 10, dapat dikatakan tidak terjadi multikolinieritas.

Tabel 11. Hasil uji multikolinearitas

\begin{tabular}{|c|c|c|c|c|}
\hline \multirow[t]{2}{*}{ Model } & \multicolumn{2}{|c|}{$\begin{array}{l}\text { Unstandardizad } \\
\text { Coefficients }\end{array}$} & \multicolumn{2}{|c|}{ Collinearity Statistic } \\
\hline & $B$ & Std Efros & Tolerance & VIF \\
\hline (Constant) & 14,554 & 2,926 & & \\
\hline Pelavanan Keiehatan & 0,105 & 0,049 & 0,870 & \\
\hline $\begin{array}{l}\text { Penyelengraran } \\
\text { Nakanan }\end{array}$ & 0,678 & 0,080 & 0,870 & 1,1 \\
\hline
\end{tabular}

a. Dependent Variable: Kexadaran Hidup Sehat

Hasilnya menunjukkan bahwa pelayanan kesehatan dan penyelenggaraan makanan menunjukkan nilai tolerance 0,870 lebih besar dari 0,10 dan nilai VIF 1,140 lebih kecil dari 10 . Dengan demikian dapat disimpulkan bahwa model regresi tersebut lolos dari uji multikolinieritas/tidak terjadi data yang multikolinearitas.

\section{Uji Hipotesis}

\section{a. Uji F}

Uji F ini bertujuan untuk menguji apakah variabel independent secara bersama-sama mampu mempengaruhi besarnya variabel dependent secara nyata/signifikan atau tidak.

Keputusan keberterimaan dari uji $\mathrm{F}$ adalah $\mathrm{F}$ hitung $>\mathrm{F}$ tabel dan nilai signifikansi $<0,05(\alpha=5 \%)$, maka $\mathrm{H} 0$ ditolak dan $\mathrm{H} 1$ diterima, sehingga dapat disimpulkan variabel bebas secara simultan berpengaruh signifikan terhadap variabel terikat. Demikian juga sebalikkan jika $\mathrm{F}$ hitung $<\mathrm{F}$ tabel dan nilai signifikansi $>0,05(\alpha=5 \%)$, maka H0 diterima dan H1 ditolak. Hipotesis simultan yang diasumsikan pada penelitian ini adalah:
H0 : Pelayanan kesehatan (X1) dan penyelenggaraan makanan (X2) secara simultan tidak berpengaruh positif dan signifikan terhadap kesadaran hidup sehat (Y)

H3: Pelayanan kesehatan (X1) dan penyelenggaraan makanan (X2) secara simultan berpengaruh positif dan signifikan terhadap kesadaran hidup sehat (Y)

Tabel 12. Uji F simultan pengaruh pelayanan kesehatan dan penyelenggaraan makanan terhadap kesadaran hidup sehat

\begin{tabular}{|c|c|c|c|c|c|c|}
\hline $\mathrm{Ma}$ & & Sun of Suxa: & $d f$ & Man Squas & $F$ & $\mathrm{Sg}$ \\
\hline & Rerestion & 987,213 & 2 & $493,607 \mid$ & 51,907 & 0,00 \\
\hline 1 & Residual & 1512,003 & 159 & 9,509 & & \\
\hline & Total & 2499,216 & 161 & & & \\
\hline
\end{tabular}

Dari hasil perhitungan tabel di atas dapat diperoleh diketahui $\mathrm{F}$ hitung $=$ $51,907>\mathrm{F}$ tabel 3,05 $(\mathrm{df} 1=2, \mathrm{df} 2=159$, $\alpha=0,05$ ), dengan nilai signifikansi $=$ $0,000<0,05$, maka H0 ditolak dan H3 diterima.

Berdasarkan hasil ini dapat disimpulkan bahwa pelayanan kesehatan dan penyelenggaraan makanan secara simultan/bersama-sama berpengaruh positif dan signifikan terhadap kessdaran hidup sehat narapidana di Lapas Kelas IIB Slawi. Hal ini berarti hipotesis ketiga penelitian dapat diterima.

\section{b. Uji t}

Uji t merupakan uji kecocokan model secara individu variabel independent (pelayanan kesehatan dan 
penyelengggaraan makanan) terhadap variabel dependent (kesadaran hidup sehat). Suatu variabel independent berpengaruh terhadap variabel dependen dilihat dari nilai $t$ hitung dan nilai signifikansi. Syarat keberterimaan uji $\mathrm{t}$ adalah thitung $>t$ tabel, dengan nilai signifikansi $<0,05$. Berikut ini adalah tabel hasil pengujian statistik uji $t$ dengan menggunakan SPSS 20.0 for Windows.

Tabel 13. Hasil uji t parsial pengaruh pelayanan kesehatan dan penyelenggaraan makanan terhadap kesadaran hidup sehat

\begin{tabular}{|c|c|c|c|}
\hline \multicolumn{2}{|c|}{ Model } & $\mathrm{T}$ & $\mathrm{Sig}$ \\
\hline & (Constant) & 4,974 & 0,000 \\
\hline 1 & Pelayanan Kesehatan & 2,142 & 0,034 \\
\hline & $\begin{array}{l}\text { Penyelenggaraan } \\
\text { Makanan }\end{array}$ & 8,522 & 0,000 \\
\hline
\end{tabular}

a. Dependent Variable: Resadaran Hidup Sehat

1). Hipotesis pertama

$\mathrm{H} 0$ : Pelayanan makanan secara parsial tidak berpengaruh positif dan signifikan terhadap kesadaran hidup sehat $(\mathrm{Y})$

H1 : Pelayanan makanan (X1) secara parsial berpengaruh positif dan signifikan terhadap kesadaran hidup sehat (Y)

Berdasarkan tabel 13 di atas dapat diperoleh penjelasan sebagai berikut: Pengujian pengaruh pelayanan makanan (X1) terhadap kesadaran hidup sehat $(\mathrm{Y})$ menghasilkan thitung $=2,142$ $>\mathrm{t}$ tabel $\mathrm{t}$ tabel 1,654 $(\mathrm{df}=160, \alpha=0,05)$, dengan nilai signifikansi $=0,034<0,05$, maka H0 ditolak dan $\mathrm{H} 1$ diterima. Berdasarkan hasil ini dapat disimpulkan bahwa pelayanan makanan berpengaruh positif dan signifikan terhadap kesadaran hidup sehat pada narapidana di Lapas Kelas IIB Slawi. Kuantitas dan kualitas dari pelayanan makanan yang semakin baik, akan meningkatkan secara positif dan signifikan terhadap kesadaran hidup sehat bagi narapidana di Lapas Kelas IIB Slawi

2). Hipotesis kedua

$\mathrm{H} 0$ : Penyelenggaraan makanan (X2) secara parsial tidak berpengaruh positif dan signifikan terhadap kesadaran hidup sehat (Y)

$\mathrm{H} 2$ : Penyelenggaraan makanan (X2) secara parsial berpengaruh positif dan signifikan terhadap kesadaran hidup sehat (Y)

Berdasarkan tabel 13 dapat diperoleh penjelasan sebagai berikut: Pengujian penyelenggaraan makanan (X2) terhadap kesadaran hidup sehat (Y) menghasilkan $\mathrm{t}$ hitung $=8,522>\mathrm{t}$ tabel $\mathrm{t}$ tabel 1,654 $(\mathrm{df}=169, \alpha=0,05)$, dengan nilai signifikansi $=0,000<0,05$, maka $\mathrm{H} 0$ ditolak dan $\mathrm{H} 2$ diterima.

Berdasarkan hasil ini dapat disimpulkan bahwa penyelenggaraan makanan berpengaruh positif dan signifikan kesadaran hidup sehat narapidana di Lapas Kelas IIB Slawi. Kuantitas dan kualitas dari penyelenggaraan makanan yang semakin baik, akan meningkatkan secara positif dan signifikan terhadap kesadaran hidup sehat narapidana di Lapas Kelas IIB Slawi.

\section{KESIMPULAN}

Berdasarkan hasil analisis data dan pembahasan pada penelitian ini dapat disimpulkan sebagai berikut:

1. Hasil analisis data penelitian pada uji F-simultan menunjukkan bahwa pelayanan kesehatan dan penyelenggaraan makanan secara simultan berperngaruh positif dan signifikan terhadap kesadaran hidup sehat bagi narapidana di Lapas Kelas IIB Slawi. 
2. Hasil analisis data penelitian pada uji t-parsial menunjukkan bahwa pelayanan kesehatan berperngaruh positif dan signifikan terhadap kesadaran hidup sehat bagi narapidana di Lapas Kelas IIB Slawi.
3. Hasil analisis data penelitian pada uji t-parsial menunjukkan bahwa penyelenggaraan makanan berperngaruh positif dan signifikan terhadap kesadaran hidup sehat bagi narapidana di Lapas Kelas IIB Slawi.

\section{DAFTAR PUSTAKA}

Buku:

Adi Sujatno, 2004, Sistem Pemasyarakatan Indonesia (Mambangun Manusia Mandiri), Jakarta: Direktorat Jenderal Pemasyarakatan Kementerian Hukum dan HAM RI

Ari Kunto, 2006, Prosedur Penelitian Suatu Pendekatan Praktek, Jakarta: Rineka Cipta

Azrul Azwar, 2004, Reformasi Sistem Pelayanan Kesehatan, Jakata: Ditjen Bina Kesmas, Departemen Kesehatan

Badan Penelitian dan Pengembangan HAM RI, Kementerian Hukum dan HAM, 2003, Pelaksanaan Standar Minimum Rules (SMR) di Lembaga Pemasyarakatan, Jakata: Badan Penelitian dan Pengembangan HAM RI, Kementerian Hukum dan HAM

Barda Nawawi Arief, 1996, Hak Hak Narapidana, Jakarta: Elsam

CI Harsono. 1995. Sistem Baru Pembinaan Narapidana. Jakarta: Djambatan

David J Cooke, Pamela and Jaqueline. 2008. Mengungkap Dunia Gelap Penjara. Jakarta: PT. Gramedia.

Direktorat Gizi Departemen Kesehatan Indonesia. 2009. Kandungan Nutrisi Bahan Makanan. Jakarta: Bharata Karya Aksara.

Dirdjosworo, Soedjono. 1992. Sejarah dan Azaz teknologi Pemasyarakatan. Bandung: Aniro

Hanke,E dan Reitsch,G. 1995. Bussiness Forecasting. Sixth Edition. New Jersey: Prentice Hall.

Notoatmodjo, Soekidjo. 2005. Metodologi Penelitian Kesehatan. Jakarta: PT. Rineka Cipta

S, Azwar.1997. Metode Penelitian. Yogyakarta: Pustaka Pelajar

Singarimbun dan Effendy, 1995, Metode Penelitian Survei, Cetakan Kedua, Penerbit PT, Pustaka LP3ES, Jakarta.

Sudjana. 2000. Metode Statistika. Bandung: Tarsito

Sugiyono, 2011, Metode Penelitian Kuantitatif, Kualitatif Dan R\&D. Bandung: Alfabeta

Umar, Husein, 2001, Riset Sumberdaya Manusia, PT, SUN, Jakarta.

Wilson. 2005. Dunia dibalik Jeruji: Kesaksian Perlawanan. Yogyakarta: Resist Book 
Jurnal Penelitian:

Adhi Akfian Yuda dan Ernawati Nina. 2012. Pengaruh Dimensi Kualitas Pelayanan dan Kepercayaan Konsumen Terhadap Kepuasan Konsumen Hotel Candi Indah Semarang. Jurnal Mahasiswa Q-MAN, Volume I, No. 3, Mei 2012, halaman 4456.

Akbar Mohammad Muzahid and Noorjahan Parvez. 2009. Impact or Service Quality, Trust, and Customer Satisfaction on Customers Loyalty. ABAC Journal Vol.29 No.1 : 24-38.

Dwi Rizkiyani dan Susanti Saragih, 2012, Stress Kerja dan Stress Kerja Dan Motivasi Kerja Pada Petugas Lembaga Pemasyarakatan, Jurnal Manajemen, Vol,12, No,1, November 2012, Universitas Maranatha.

Herman , 2010, Pengaruh Kualitas Pelayanan Terhadap Kepuasan Pasien Rawat Inap di rumah Sakit Umum Daerah Kabupaten Subang. Diakses tanggal 4 Oktober 2016 dari http://elib.unikom.ac.id/gdl.php?mod=browse\&op $=$ read\&id=jbptunikomppgdl-s1-2003-hermannim2-127

http://www. id.wikipedia.org/wiki/Kesadaran, Diunduh pada Tanggal 5 Oktober 2016

http://www.pscyologymania.com/2012/10/pengertian-narapidana.html, diakses tanggal 3 oktober 2016

Lunquist Anna and Alinder Johan. 2007. Driving after brain injury: self awareness and coping at the tactical level of control. Journal btain injury volume 21, 2007, pages 1109-1117. Francis: Taylor Francis online

Ria Satyawati dan Wayan Suartana, 2014, Pengaruh Gaya Kepemimpinan Dan Budaya Organisasi Terhadap Kepuasan Kerja Yang Berdampak Pada Kinerja Keuangan, E-jurnal Akuntansi Universitas Udayana 6,1

$\underline{\text { Tesis: }}$

Mohammad Farid Aulia. 2015. Implementasi Hak Mendapatkan Pelayanan Kesehatan dan Makanan yang layak bagi narapidana di Lembaga Pemasyarakatan Kelas IIA Minasa Sunggu

Media cetak:

Prof. Dr. Hibnu Nugroho SH, MH. 2016. Reformasi Hukum Lembaga Pemasyarakatan. Surat Kabar Suara Merdeka tanggal 24 Oktober 2016.

Peraturan Perundang-Undangan:

, Undang - Undang Nomor 12 Tahun 1995 Tentang Pemasyarakatan.

, Undang - Undang Nomor 36 Tahun 2009 Tentang Kesehatan.

, Peraturan Pemerintah, Nomor 32 Tahun 1999 Tentang Syarat dan Tata

Cara Pelaksanaan Hak Warga Binaan. 
Peraturan Pemerintah, Nomor 39 Tahun 1999 Tentang Hak Asasi Manusia.

Surat Keputusan Menteri Kehakiman dan Hak Asasi Manusia RI Nomor: M.01.PR.07.10 Tahun 2001 tenteng Organisasi dan Tata Kerja Departemen Kehakiman dan Hak Asasi Manusia RI.

Republik Indonesia, 1945, Undang-Undang Dasar Republik Indonesia Tahun 1945. 